\author{
Robert Kołodziej \\ (Wydział Nauk Historycznych i Pedagogicznych \\ Uniwersytet Wrocławski)
}

\title{
Litewski sejmik generalny w Słonimiu na tle sytuacji w Rzeczypospolitej przed sejmem 1685 roku
}

\author{
Lithuanian general sejmik in Słonim in the light of the situation \\ in the Commonwealth before the 1684 Sejm
}

\begin{abstract}
STRESZCZENIE:
Sejmik generalny Wielkiego Księstwa Litewskiego w pierwszej poł. XVII w. stał się instytucją martwą. Dlatego wielkie wrażenie w całym kraju wywołało zorganizowanie przez Litwinów tego typu zjazdu w Słonimiu w 1685 r. Za jego sukcesem stały połączone siły Sapiehów i Radziwiłłów, którzy przez krótki okres zjednoczyli swoje siły przeciw królowi. Duże znaczenie dla powodzenia tej inicjatywy miała decyzja króla i rady senatu, na mocy której sejm z 1685 r. został przeniesiony z Grodna do Warszawy. Wywołało to protesty Litwinów, których tym łatwiej można było podburzyć przeciw polityce dworu. Zebrani w Słonimiu obywatele Wielkiego Księstwa wysłali kilku swoich przedstawicieli na sejm do Warszawy, aby ci blokowali wybór marszałka. Natomiast większość uczestników zjazdu słonimskiego udała się do Grodna, a więc na miejsce, w którym zgodnie z prawem miał odbyć się sejm. Dopiero po kilku tygodniach negocjacji królowi udało się przekonać Litwinów do zgody i przyjazdu do Warszawy. Osiągnęli jednak swój cel - zamanifestowali królowi swoje niezadowolenie i przeszkodzili w świętowaniu wiktorii wiedeńskiej, która miała być elementem wzmacniania autorytetu monarszego. Podczas obrad sejmowych uchwalono nową konstytucję, asekurującą sejm w Grodnie. Wydarzenia z 1685 r. nie miały jednak wpływu na samą instytucję sejmiku generalnego litewskiego, który w następnych latach pozostał martwym tworem.
\end{abstract}

Słowa kluczowe: sejm, sejmik, sejmik generalny, Wielkie Księstwo Litewskie, parlamentaryzm, Jan III Sobieski, Sapiehowie, Radziwiłłowie, Grodno, Słonim

Problematyka związana z funkcjonowaniem sejmików generalnych w dawnej Rzeczypospolitej jest od lat obiektem zainteresowań badaczy epoki staropolskiej. Sejmiki generalne Prus Królewskich i Mazowsza, 
a ostatnio Litwy doczekały się już rzetelnych opracowań monograficznych ${ }^{1}$. Brakuje ciągle wyczerpujących prac dotyczących sejmików Wielkopolski i Małopolski. Bez wątpienia wpływ na to ma fakt, że o ile sejmiki mazowiecki i pruski funkcjonowały przez cały okres istnienia Rzeczypospolitej szlacheckiej, to "generały" wielkopolski i małopolski zanikły już na początku wieku XVII, jeśli nie liczyć incydentalnie zorganizowanego zjazdu Małopolan w Nowym Mieście Korczynie w czasie bezkrólewia w 1669 roku $^{2}$. Sejmik generalny litewski, który jeszcze w XVI wieku funkcjonował dość regularnie, od początku XVII w. zbierał się coraz rzadziej. Według badań Andrzeja Rachuby ostatni taki zjazd za panowania Wazów odbył się w 1632 r. W późniejszym czasie zjazdy słonimskie nie były organizowane i wszystko wskazywało na to, że podzielą one losy sejmików w Kole i Nowym Mieście Korczynie. Jednak po trwającej pięćdziesiąt trzy lata przerwie sejmik ten został zupełnie niespodziewanie reaktywowany. W 1685 r., podczas trwania kampanii przedsejmowej na Litwie, rozpoczęto bowiem przygotowania do odbycia sejmiku generalnego $\mathrm{w}$ tradycyjnym jego miejscu obrad, a więc w Słonimiu. Wieść o tym przyjęta została w kraju z niedowierzaniem i ogromnym zaskoczeniem. Aby zrozumieć przyczyny nieoczekiwanego zebrania się sejmiku, należy przyjrzeć się ówczesnym uwarunkowaniom politycznym w Rzeczypospolitej, a przede wszystkim na Litwie.

Z pewnością ogromną rolę w sytuacji wewnętrznej Wielkiego Księstwa Litewskiego odegrała wymiana elit, jaka nastąpiła na początku lat osiemdziesiątych XVII w. Zmiany te związane były ze śmiercią dotychczasowych decydentów litewskich. Ze sceny politycznej odeszli przede wszystkim zdecydowani przeciwnicy Sobieskiego - dwaj najbardziej wpływowi przedstawiciele rodziny Paców. W 1682 r. zmarł Kazimierz Michał, wojewoda wileński i hetman wielki litewski, a jednocześnie nieprzejednany wróg króla. Dwa lata później, w 1684 r., odszedł również Krzysztof Pac, kanclerz litewski. Z drugiej strony król stracił również ważnych współpracowników, wspierających go w Wielkim Księstwie. W roku 1679 zmarł Aleksander Hilary Połubiński, marszałek wielki litewski, który pod

${ }^{1}$ J. A. Gierowski, Sejmik generalny księstwa mazowieckiego na tle ustroju sejmikowego Mazowsza, Wrocław 1948; Z. Naworski, Sejmik generalny Prus Królewskich 1569-1772. Organizacja i funkcjonowanie na tle systemu zgromadzeń stanowych prowincji, Toruń 1992; S. Achremczyk, Życie sejmikowe Prus Królewskich w latach 1647-1772, Olsztyn 1999; A. Rachuba, Wielkie Księstwo Litewskie w systemie parlamentarnym Rzeczypospolitej w latach 1569-1763, Warszawa 2002, s. 152-166; idem, Sejmiki generalne Wielkiego Księstwa Litewskiego w Wołkowysku i Słonimiu, [w:] Między Zachodem a Wschodem. Studia z dziejów Rzeczypospolitej w epoce nowożytnej, red. J. Staszewski, K. Mikulski, J. Dumanowski, Toruń 2002, s. 42-53.

${ }^{2}$ Zob. „Laudum województwa krakowskiego”, 18 II 1669, BCz, 1865, s. 157-173; por. W. Kriegseisen, Samorzad szlachecki w Małopolsce w latach 1669-1717, Warszawa 1989, s. 32. 
koniec życia aktywnie współpracował z dworem. Jeszcze większą stratą była jednak śmierć Michała Kazimierza Radziwiłła podkanclerzego i hetmana polnego litewskiego, a jednocześnie królewskiego szwagra, zmarłego podczas podróży dyplomatycznej do Italii w $1680 \mathrm{r}$. W naturalny sposób następowała więc wymiana pokoleniowa, która stawiała przed monarchą szanse na stworzenie w Wielkim Księstwie trwałego oparcia dla polityki króla. Sobieski zdecydował, aby najwyższe urzędy na Litwie oddać w ręce Sapiehów i Radziwiłłów. Nie może to dziwić, jako że oba rody w początkach panowania Jana III aktywnie wspierały politykę króla. Dlatego już wcześniej (w 1676 r.) zasłużony dla monarchy Benedykt Paweł Sapieha, który w 1674 r. pełnił funkcję marszałka sejmu elekcyjnego, otrzymał urząd podskarbiego litewskiego. Z kolei jego brat, Kazimierz Jan, został wojewodą wileńskim i hetmanem wielkim litewskim. Niejako dla przeciwwagi dla rodu Sapiehów urząd marszałka wielkiego po śmierci A. H. Połubińskiego otrzymał Stanisław Kazimierz Radziwiłł, zaś urząd podkanclerzego - Dominik Mikołaj Radziwiłł. Wydawało się, że po śmierci Paców opozycyjna dotąd Litwa znajdzie się w szeregach prowincji jeśli nie popierających króla, to przynajmniej życzliwie neutralnych. Rachuby króla w tym zakresie jednak zawiodły. Radziwiłłowie byli wówczas pozbawieni charyzmatycznych polityków, którzy potrafiliby skutecznie działać na sejmikach i konsekwentnie budować swój obóz polityczny. Dlatego wsparcie z ich strony było niewielkie. Natomiast Sapiehowie wkrótce przeszli na stanowisko skrajnie opozycyjne wobec Sobieskiego, przejmując do swojego obozu dawnych członków stronnictwa pacowskiego. Analiza tego problemu i motywów kierujących Sapiehami wymagałaby z pewnością odrębnych badań, warto jednak poświęcić jej choćby kilka uwag. Zbigniew Wójcik, analizując sapieżyńską woltę, zwracał uwagę na kluczową rolę polityki zagranicznej: próbę przywrócenia zerwanych w 1683 r. kontaktów dyplomatycznych z Francja, przybycie na dwór polski markiza de Bethune i misję do Wersalu podkanclerzego koronnego Jana Wielopolskiego w 1684 r. Dochodziły do tego kwestie ambicjonalne, związane ze wzrostem autorytetu i popularności króla w kraju po wiktorii wiedeńskiej. Zaniepokojeni tymi wydarzeniami magnaci koronni i litewscy mieli z tego powodu zawiązać spisek czy może bardziej nieformalne porozumienie. Podczas tajnego spotkania w Warszawie w $1684 \mathrm{r}$. omawiali ewentualną współpracę mającą na celu niedopuszczenie do wzmocnienia władzy królewskiej oraz zainicjowanie działań dyplomatycznych, których konsekwencją byłoby osłabienie pozycji Sobieskiego w kraju . Z pewnością na zmianę postawy Sapiehów wpłynąć mógł rów-

${ }^{3}$ Z. Wójcik, Jan Sobieski, Warszawa 1994, s. 419. Do „spisku” mieli należeć Krzysztof Grzymułtowski, Stanisław Lubomirski, Benedykt Sapieha. Do sugerowanego przez Wójci- 
nież fakt kolportowania anonimowej publicystyki, krytykującej hetmana litewskiego K. Sapiehę za nieudolne działania militarne i spóźniony marsz w kierunku Wiednia ${ }^{4}$. Wprawdzie nie wiadomo, czy za tymi pismami stał rzeczywiście dwór, ale kogo innego mogli Sapiehowie podejrzewać o ich inspirację? Paszkwile z pewnością dotknęły do żywego Kazimierza Sapiehę, niezwykle czułego na punkcie swoich umiejętności wojskowych ${ }^{5}$. Na ile natomiast powstanie opozycji sapieżyńskiej miało związek z tzw. polityką dynastyczną Sobieskiego, jest sprawą dalece dyskusyjną. Poszukiwania odpowiedniej kandydatki na żonę dla Jakuba, najstarszego syna królewskiego, rozpoczęte około 1684 r., nie były groźne z punktu widzenia wolności szlacheckich, tym bardziej, że ówczesne przymiarki wskazywały na egzotyczną z polskiego punktu widzenia kandydaturę infantki portugalskiej ${ }^{6}$. Pozostaje jeszcze sugerowana przez niektórych badaczy próba elekcji vivente rege, rzekomo forsowana przez Sobieskiego, a to z pomocą Tatarów, a to znów z pomocą Francji. Jej przejawem miało być uczestnictwo królewicza $w$ radach senatu i sadzanie go obok ojca pod baldachimem królewskim. Pierwszy taki przypadek miał prawdopodobnie miejsce już na początku 1685 roku, skoro podczas zjazdu litewskiego w Grodnie w tym samym roku obecna tam szlachta ostro atakowała monarchę za ustawienie krzesła dla królewicza obok tronu królewskiego ${ }^{7}$. Ponownie w 1686 r. królewicz Jakub wziął udział w radzie senatu i zasiadł pod baldachimem podczas audiencji posłów moskiewskich ${ }^{8}$. Czy można jednak tym faktem usprawiedliwić tezę, że było to przygotowanie do elekcji vivente rege? Zdaje się to wątpliwe, bo przecież dokonanie zamachu stanu przez Sobieskiego było w praktyce niemożliwe do realizacji i sprawę z tego zdawać sobie musiał i król, i magnaci. Była więc raczej tzw. polityka dynastyczna wygodnym pretekstem, a nie przyczyna, straszakiem używanym przez opozycję, nad wyraz często występującym

ka udziału w porozumieniu Stanisława Jabłonowskiego raczej z dystansem odniósł się autor obszernej biografii hetmana, zob. M. Wagner, Stanisław Jabłonowski (1634-1702). Polityk i dowódca, t. 1, Siedlce 1997, s. 193-194.

${ }^{4}$ W. Semkowicz, Udział wojsk litewskich Sobieskiego w kampanii roku 1683, „Ateneum Wileńskie" 1934, 9, s. 7-20.

${ }^{5}$ Świadczy o tym choćby fragment listu Sapiehy, w którym skarżył się: Prawda, żem nie byt na dwóch kampaniach, alem ich nie unikat, jako tam po pokojach pańskich przestronnej gemby latały głosy, zob. K. Sapieha do S. Szczuki, b.m., 23 III 1687, BCz, 431, s. 535.

${ }^{6}$ Losy szukania żony dla Jakuba przedstawiła ostatnio w wyczerpującej publikacji A. Skrzypietz, Królewscy synowie - Jakub, Aleksander i Konstanty Sobiescy, Katowice 2011, s. 113 passim; o infantce portugalskiej zob. s. 142-144.

${ }^{7}$ Stanisław Niemira, podczaszy podlaski do Marcina Zamoyskiego, wojewody lubelskiego, Grodno 21 II 1685, Archiwum PAN, 398, Teki Wolińskiego, 69, k. 359.

${ }^{8}$ Z. Wójcik, op. cit., s. 423-424. 
w antykrólewskiej publicystyce. Wydaje się, że tego typu oskarżenia niewiele miały wspólnego z rzeczywistymi działaniami dworu, a były raczej próbą osłabienia autorytetu króla w szerokich masach słabo wyrobionej politycznie, podatnej na agitację szlachty. Podobny mechanizm działał wszakże w latach rokoszu Zebrzydowskiego, gdy w publicystyce politycznej pojawiały się tak częste, jak bezpodstawne oskarżenia, że Zygmunt III chce dokonać elekcji vivente rege i koronować swego syna Władysława Zygmunta9. Przejście rodziny Sapiehów w szeregi opozycji nie było więc wynikiem posadzenia królewicza pod baldachimem, ale wynikało z chłodnej i skalkulowanej decyzji magnatów litewskich uważających, że polityka antykrólewska może im przynieść więcej korzyści.

Zupełnie inaczej sytuacja przedstawiała się w przypadku stosunków Sobieskiego z „domem radziwiłłowskim”. Król nieoczekiwanie w 1684 r. zdecydował o nadaniu pieczęci wielkiej litewskiej Marcjanowi Ogińskiemu wojewodzie trockiemu, związanemu wcześniej z Pacami. Przyczyny tej decyzji były złożone. W posiadaniu Ogińskiego mogły znajdować się jakieś materiały obciążające Sobieskiego, które w dramatycznych okolicznościach przejął on po śmierci Michała Kazimierza Paca ${ }^{10}$. Pozyskanie tego polityka było więc dla króla ważne, tym bardziej, że flirtował on od pewnego czasu z Sapiehami. Nominacja okazała się jednak wielkim błędem. Królowi nie tylko nie udało się pozyskać Ogińskiego, który wkrótce stał się aktywnym członkiem partii sapieżyńskiej. Pominął bowiem Sobieski Dominika Radziwiłła, dotychczasowego podkanclerzego, człowieka wprawdzie nieudolnego, jednak z pewnością dla dworu nieszkodliwego. Nominacja dla Ogińskiego spotkała się z gwałtowną reakcją zawiedzionego Radziwiłła, rozsyłającego na sejmiki litewskie pełne oburzenia listy ${ }^{11}$. Tym samym do opozycyjnych Sapiehów niespodziewanie w 1684 r. dołączyli, przynajmniej na jakiś czas, przychylni dotąd królowi Radziwiłłowie.

W tak niekorzystnych dla siebie warunkach politycznych rozpoczęto w $1684 \mathrm{r}$. procedurę zwoływania kolejnego, pierwszego po wiktorii wiedeńskiej sejmu. Jego kadencja zgodnie z prawem przypadała na Grodno, bowiem dwa ostatnie zjazdy odbyły się w Warszawie. Fakt ten nie był

${ }^{9}$ Zob. Pisma polityczne z czasów rokoszu Zebrzydowskiego 1606-1608, wyd. J. Czubek, t. 1-3, Kraków 1916-1918.

${ }^{10}$ Mikołaj Stefan Pac, biskup wileński do Jana III, z Chorosczy, 18 V 1682, Nacyjanalny Gistaryczny Archiu Bielarusi w Mińsku, F. 695, op. 1, nr 102, s. 7-10a; K. Bobiatyński, Michał Kazimierz Pac - wojewoda wileński, hetman wielki litewski, Warszawa 2008, s. 413-414. Według informacji przekazywanych na dwór kompromitujące materiały miały zostać spalone.

${ }^{11}$ A. Malejka, Spór o pieczęć wielka litewską w latach 1684-1685. Z dziejów polityki nominacyjnej Jana III Sobieskiego, „Studia Historyczne” 2001, 44, 2, s. 301-311. 
jednak na rękę królowi, który od dłuższego czasu myślał o przeniesieniu obrad do Korony. Oczywiście działania Sobieskiego zdawały się racjonalne i uzasadnione, a prowadzenie intensywnych działań wojennych przeciw Imperium Osmańskiemu nie sprzyjało wyjazdowi króla i hetmanów do dalekiego Grodna. Dodatkowym czynnikiem była niewygoda samego miasta. Zarówno monarcha, jak i szlachta doskonale pamiętali ostatni sejm grodzieński z lat 1678/1679, który udowodnił, że miasto nie było przygotowane na podjęcie wielotysięcznych tłumów przybywających na obrady sejmowe. Co więcej, mimo kolejnych kwot asygnowanych na przysposobienie Grodna do roli gospodarza sejmów, w roku 1684 na radzie senatu zauważano, że miejscowy zamek jest „zrujnowany” i nie nadaje się do sejmowania ${ }^{12}$. Dlatego proponował Sobieski przeniesienie obrad $\mathrm{w}$ inne miejsce ${ }^{13}$. Początkowo forsował kandydaturę Lwowa jako miasta położonego blisko teatru działań wojennych. Po chłodnym przyjęciu przez senatorów tego pomysłu zaproponował król ostatecznie zorganizowanie sejmu w Warszawie. Miejsce to zatwierdziła rada senatu, odprawiona 22 listopada 1684 r. w Żółkwi. Król nie omieszkał w uniwersale przedsejmowym podkreślić, że $\mathrm{w}$ radzie tej brali udział również senatorowie z Litwy ${ }^{14}$.

Okazało się, że decyzja ta była kolejnym błędem popełnionym przez króla. Zmiana miejsca obrad sejmowych została bowiem wykorzystana przez opozycję antykrólewską do podburzenia szlachty litewskiej, niezwykle wyczulonej na punkcie nowo wprowadzonego prawa o sejmie grodzieńskim $^{15}$. W instrukcjach sejmików litewskich pojawiły się zapisy, że obywatele Wielkiego Księstwa nie wyrażają zgody na decyzję rady senatu i przeniesienie sejmu do Warszawy. W ten sposób uzasadniona, ale nieroztropna decyzja podjęta przez monarchę stała się kanwą zwołania w nadzwyczajnym trybie litewskiego sejmiku generalnego w Słonimiu, w tradycyjnym więc miejscu jego zjazdów. Należy przy tym zauważyć, że opozycja wykorzystała również fakt, iż sama szlachta litewska od wielu lat postulowała reaktywację sejmiku generalnego ${ }^{16}$. Tego typu hasła

\footnotetext{
${ }^{12}$ R. Kołodziej, Ostatni wolności naszej klejnot. Sejm Rzeczypospolitej za panowania Jana III Sobieskiego, Poznań 2014, s. 111.

${ }^{13}$ Perturbacje związane z miejscem sejmowania omówiła B. Górna, Przygotowanie do zwołania sejmu w 1685 roku, [w:] Studia z dziejów XVII i XVIII w., red. K. Matwijowski, B. Rok, „Prace Historyczne” 33, Wrocław 2003, s. 53-55.

14 „Rada senatu 22 XI 1684”, AGAD, APP, 48, s. 16-17; w uniwersale zapisano, że miejsce sejmu ustalono za rada $i$ zdaniem panów rad obojga narodów przy boku naszym zostającym, zob. „Uniwersał Jana III”, Żółkiew, 24 XI 1684, AP Poznań, Gr Wschowa, 150, k. 289v.

${ }^{15}$ Konstytucja „Seym trzeci w Wielkim Xsię. Litew.”, uchwalona została w roku 1673, zob. VL, t. V, s. 67.

${ }^{16}$ A. Rachuba, Wielkie Księstwo..., s. 162-163.
} 
można znaleźć także w instrukcjach litewskich z czasów Jana III. O zjazd słonimski upominała się w 1682 r. choćby szlachta nowogrodzka, a obywatele słonimscy, najbardziej zainteresowaniu w restytucji odbywającego się w ich mieście sejmiku, kilkakrotnie zapisywali w instrukcji dla posłów punkt zjazd słonimski, że abolevit, lubo prawo jest dawne, serio instabunt, aby był znowu resuscitatus ${ }^{17}$. Pod wpływem postulatów prowincjonalnych i za staraniem posłów litewskich na pierwszym sejmie grodzieńskim w 1679 r. uchwalono nawet konstytucję reasumująca prawo o obradach sejmiku generalnego w Słonimiu ${ }^{18}$. Jednak od deklaracji do realizacji pozostawała długa droga. $W$ instrukcjach szlacheckich roiło się od nigdy niezrealizowanych postulatów, a Volumina Legum pełne były reasumowanych, a nieprzestrzeganych praw. Warto przy tym zauważyć, że i szlachta koronna w omawianym okresie domagała się przywrócenia zaniechanych „generałów". Podczas kaptura w czasie bezkrólewia w 1673 r. uchwalono prawo, w którym apelowano o przywrócenie sejmików generalnych ${ }^{19}$. Postulaty o ich reaktywacji znaleźć można w ówczesnych instrukcjach szlachty sandomierskiej i krakowskiej z Małopolski czy sieradzkiej z Wielkopolski ${ }^{20}$. Sejmik średzki zdecydował się nawet na podjęcie oddolnej inicjatywy mającej na celu odrodzenie "generału" wielkopolskiego, wysyłając w 1680 r. listy do innych sejmików i zobowiązując swoich posłów, aby ci zjechali na wyznaczony uniwersałem termin do Koła na sejmik generalny ${ }^{21}$. Wszystkie te działania, zarówno szlachty koronnej, jak i litewskiej, miały niewielkie szanse na wskrzeszenie sejmików generalnych, na które zwyczajnie nikt nie przyjeżdżał. W tym świetle sejmik w Słonimiu w 1685 r. wygląda rzeczywiście na ewenement, nie pozostawiając wątpliwości, że jego zwołanie było wynikiem intensywnych starań i działań o charakterze politycznym. Stała za nimi oczywiście partia sapieżyńska, wsparta przez zrażonych do króla Radziwiłłów. Hasła, powta-

17 „Instrukcja nowogródzka”, 16 XII 1682, AGAD, AR II, 1708, s. 2; „Instrukcja słonimska”, 31 XII 1675, Lietuvos Mokslų Akademijos biblioteka, F 17-57, k. 4; „Instrukcja słonimska", 3 XII 1680, ibidem, k. 12.

18 „Reassumptio konstytucyi o mieyscu Seymikowania w Słonimie”, VL, t. V, s. 307; w konstytucji zapisano, że jest ona uchwalona na prośbę posłów słonimskich, co oznacza, że również w instrukcji przed sejmem grodzieńskim 1678 r. taki postulat znalazł się $\mathrm{w}$ instrukcji powiatu słonimskiego.

19 "Seymików y Seymów odprawowania norma”, VL, t. V, s. 106.

20 "Instrukcja opatowska”, 10 XII 1676, B PAU PAN Kraków, 8338, k. 580; „Instrukcja opatowska”, 16 XII 1693, B PAU PAN Kraków, 8338, k. 778; „Instrukcja proszowicka”, 29 XI 1678, Akta sejmikowe województwa krakowskiego, t. IV, opr. A. Przyboś, Wrocław 1963, s. 99; „Instrukcja proszowicka”, 5 XI 1688, ibidem, t. V, opr. idem, Wrocław 1984, s. 77; „Instrukcja sieradzka", 31 XII 1675, B PAU BAN Kraków, 8343, s. 350; ponowny postulat na ten temat zob. „Instrukcja sieradzka”, 3 XI 1678, B PAU PAN Kraków, 8343, s. 482.

${ }^{21}$ „Laudum sejmiku średzkiego”, 3 XII 1680, AP Poznań, Gr Wschowa, 149, k. 165v. 
rzane od lat na sejmikach przedsejmowych, dały możliwość sfinalizowania akcji, a dodatkowym argumentem, w kapitalny sposób ułatwiającym opozycji działanie, było jawne łamanie przez króla i senat praw litewskich i lekceważenie konstytucji o sejmie grodzieńskim. Na sejmikach przedsejmowych na Litwie szlachta nakazywała posłom przybyć do Słonimia na sejmik generalny. Na sejmiku wileńskim zapisano w instrukcji dla posłów, żeby według tego prawa statutowego, tam do Stonimia niedziel dwoma przed sejmem zjachali i tam z inszych województw i powiatów z ichm. panami posłami [...] consecrationis prawa o sejmie grodzieńskim ${ }^{22}$. Udać się na sejmik słonimski nakazali też swoim posłom obywatele powiatu nowogródzkiego, zapisując $\mathrm{w}$ instrukcji, że zjazd słonimski jest potrzebny dla porozumienia się stanów ${ }^{23}$. Zamieszczenie $w$ instrukcjach litewskich punktów o sejmiku generalnym wskazuje, że akcja zwołania "generału” była więc starannie przemyślana i zaplanowana. Rzeczywiście, poprzedziło ją spotkanie zorganizowane w Wilnie przez opozycjonistów, na którym zaplanowano działania w całej prowincji, które miały na celu niedopuszczenie do przeniesienia sejmu do Warszawy. Na sejmikach obowiązywała wielka mobilizacja. Opozycja była zdecydowana rwać zjazdy, na których wybrani byliby posłowie prokrólewscy. Co więcej, Radziwiłłowie starali się nie dopuścić do wyboru osób związanych z nowym kanclerzem litewskim M. Ogińskim, a ofiarą stał się choćby Szymon Karol Ogiński miecznik W. Ks. Lit. Kwestionowano na sejmikach również uniwersały królewskie wydawane z kancelarii wielkiej litewskiej, uznając je za nielegalne, jako że urząd kanclerski nie został nadany Ogińskiemu podczas sejmu. Doniesienia z Litwy wskazują że opozycja nie szczędziła grosza na jednanie sobie szlachty litewskiej i wybranych na sejmikach posłów ${ }^{24}$. Aby zachęcić obywateli do udziału w sejmiku generalnym, Sapiehowie dodatkowo zaplanowali w jego trakcie przeprowadzenie aktu weselnego Jerzego Karola Chodkiewicza, oboźnego litewskiego, z Marianną Naruszewiczówną siostrzenicą Sapiehów. O zainteresowaniu przybyciem do Słonimia licznego grona szlachty świadczy informacja o wcześniejszym rezerwowaniu sobie gospód w mieście ${ }^{25}$.

Nawet jednak tak starannie zaplanowana akcja budziła wśród szlachty wątpliwości, czy planowany zjazd rzeczywiście dojdzie do skutku.

22 „Instrukcja sejmiku wileńskiego przedsejmowego pro die 5 I 1685”, BN, BOZ, 1809, t. 2. k. $876 \mathrm{v}$.

${ }^{23}$ "Instrukcja nowogródzka”, 5 I 1685, AGAD, AR II, 1730, s. 2.

${ }^{24}$ "Pewne przestrogi z Księstwa Litewskiego", AGAD, AZ, 3047, s. 159.

${ }^{25} \mathrm{Na}$ staranne przygotowanie akcji zwrócił uwagę A. Rachuba, Wielkie Księstwo..., s. 164; "Z Wilna, 20 I 1685”, AGAD, APP, 162, s. 123; "List z rozmaitemi doniesieniami do Warszawy 1685 r. z Lwowa pisany", BCz, 181, s. 11-12. 
Dlatego szlachta na sejmikach partykularnych nakazywała posłom, aby w razie niepowodzenia "generału" od razu udali się na sejm do Warsza$w^{26}$. Widocznie i niektórzy senatorowie mieli wątpliwości, czy jechać do Słonimia, skoro Marcjana Ogińskiego, kanclerza litewskiego, próbowano zawrócić listownie z drogi do Żółkwi z zapewnieniami, że generał ma koniecznie bez najmniejszego zawodu dojśćn ${ }^{27}$. Osobną kwestią pozostaje, czy nowo mianowany kanclerz litewski miał ochotę jechać do Słonimia i konfrontować się z Radziwiłłami - dlatego udział Ogińskiego w sejmiku zdaje się nie tylko mocno wątpliwy, ale raczej wykluczony.

O przebiegu samego sejmiku nie mamy zbyt wielu informacji. Jako pierwszy przyczyny zjazdu próbował zanalizować Gottfried Lengnich ${ }^{28}$. Ostatnio wydarzenia z nim związane omawiali A. Rachuba oraz Henryk Lulewicz ${ }^{29}$. Największym problemem jest brak oficjalnych dokumentów sejmikowych, a szczątkowy stan zachowania ksiag grodzkich słonimskich nie daje wielkich nadziei na ich odnalezienie ${ }^{30}$. Nieliczne i bardzo skromne informacje o obradach pochodzą ze źródeł pośrednich, korespondencji i diariusza Stanisława Niezabitowskiego, obecnego wówczas w Słonimiu, oraz od - zazwyczaj dobrze poinformowanych - rezydentów brandenburskich.

Nie do końca wiadomo, jaka była frekwencja na sejmiku generalnym. $Z$ informacji krążących po kraju wynikało, że do Słonimia wybierali się biskupi wileński Aleksander Kotowicz, żmudzki Kazimierz Pac, smoleński Konstanty Brzostowski, Cyprian Paweł Brzostowski wojewoda i Jan Kazimierz Kierdej kasztelan trocki, a także Piotr Pac starosta żmudzki ${ }^{31}$. O ile były to plotki, a o ile deklaracje, trudno jednoznacznie

26 „Ekstrakt z instrukcji posłów wileńskich 1685 r.”, AGAD, AR II, 1739, s. 1; „Instrukcja sejmiku wileńskiego przedsejmowego pro die 5 I 1685", BN, BOZ, 1809, t. 2. k. 877.

${ }_{27}$ „List z rozmaitemi doniesieniami do Warszawy 1685 r. z Lwowa pisany", BCz, 181, s. 11-12.

${ }^{28}$ G. Lengnich, Geschichte der preußischen Lande polnischen Antheils unter der Regierung der Könige Michaels und Johann des dritten, t. VIII, Danzig 1748, s. 244-246.

${ }^{29}$ A. Rachuba, Wielkie Księstwo..., s. 163-164; idem, Sejmiki generalne..., s. 51-52; Akta zjazdów stanów Wielkiego Księstwa Litewskiego, t. II: Okresy panowania królów elekcyjnych XVIXVII wiek, opr. H. Lulewicz, Warszawa 2009, s. 394. Aspekty związane z działalnością propagandową przed sejmem 1685 r. omówiono w pracach: B. Górna, Antykrólewska propaganda opozycji (od bitwy wiedeńskiego do sejmu 1685 r.), "Sobótka” 1996, 51, 1-3, s. 147-152; A. Czarniecka, "Nikt nie stuchat mnie za życia”. Jan III Sobieski w walce z opozycyjna propaganda (1684-1696), Warszawa, 2009, s. 105-145.

${ }^{30}$ Z 1685 r. pochodzi jedyna zachowana księga grodzka słonimska, nie zawiera ona akt dotyczących sejmiku generalnego, zob. Gistoryczny Archiw Belarusy w Mińsku, Fond 1737, Księgi grodzkie słonimskie, Opis 1, nr 25 (księga z lat 1685-1689).

${ }^{31}$ A. Rachuba, Wielkie Księstwo..., s. 164; „List z rozmaitemi doniesieniami do Warszawy 1685 r. z Lwowa pisany", BCz, 181, s. 11-12. 
stwierdzić. Nie wszyscy z wymienionych w Słonimiu się zjawili, choćby z późniejszej deklaracji Cypriana Pawła Brzostowskiego, wojewody trockiego, wywnioskować można, że do Słonimia nie pojechał ${ }^{32}$. Część obecnych zapewne szybko wyjechała. Ostatecznie wszystkich posłów i senatorów przybyło z pewnością nieco ponad trzydziestu, a więc zapewne nie wszyscy posłowie $z$ Litwy stawili się na generale ${ }^{33}$. $Z$ drugiej jednak strony, porównując frekwencję do tej na sejmikach generalnych z końca XVI w. i początku XVII w., należy uznać ją za bardzo dobrą ${ }^{34}$. Wśród zebranych w Słonimiu senatorów znaleźli się: Benedykt Sapieha podskarbi litewski, Kazimierz Sapieha wojewoda wileński i hetman wielki litewski, Dominik Radziwiłł podkanclerzy litewski, Stanisław Radziwiłł marszałek wielki litewski, Stefan Kurcz wojewoda brzeski litewski, Karol Wilczek kasztelan smoleński oraz Jan Korsak kasztelan połocki ${ }^{35}$.

Termin sejmiku generalnego przypadał, zgodnie z III Statutem Litewskim, na dwa tygodnie przed sejmem walnym, choć w praktyce Wielkiego Księstwa znanych było wiele odstępstw od tej reguły ${ }^{36}$. Tak też było i w tym przypadku, ponieważ zgodnie z prawem sejmik powinien zaczać się 2 lutego. Sejmiki generalne w Koronie wyznaczone zostały przez króla w uniwersale na 5 lutego 1685 r. Szlachta litewska zaczęła gromadzić się w Słonimiu znacznie wcześniej, bo już pod koniec stycznia. Jednak obrady były sukcesywnie odwlekane. Być może czekano na większą frekwencję posłów i senatorów. Dopiero bowiem 6 lutego rozpoczęły się konsultacje prywatne, a nazajutrz (7 lutego) zainaugurowano obrady publiczne. Nie wiadomo, gdzie się one odbywały, ale prawdopodobnie $\mathrm{w}$ tradycyjnym miejscu, czyli w pomieszczeniach zamku słonimskiego ${ }^{37}$. Z pewnością nie było na sejmiku posła królewskiego, którego obecność na wcześniejszych sejmikach generalnych była raczej normą. To nadawało samemu zjazdowi charakter na wpół legalny, choć przecież sejmik oficjalnie był przez króla zwołany uniwersałem przedsejmowym. O ile jednak na wcześniejszych generałach litewskich brak królewskiego legata mógł stać się powodem niedojścia sejmiku do skutku ${ }^{38}$, to tym razem zebrani, z oczywistych

\footnotetext{
${ }^{32}$ Cyprian Paweł Brzostowski, wojewoda trocki do Stanisława Sarnowskiego, Wilno, 27 I 1685, BCz, 1376, s. 570-571.

${ }^{33}$ Stanisław Niezabitowski do Zbigniewa Morsztyna, miecznika mozyrskiego, Słuck, 12 II 1685, AGAD, AR V, 10481/V, s. 21-24.

${ }^{34}$ A. Rachuba, Sejmiki generalne..., s. 48.

35 "Journal des polnischen Reichstags de anno 1685", Geheimes Staatsarchiv Preussische Kulturbesitz Berlin-Dahlem, I HA, Rep. 9, 27.k.3, k. 5; „Regestr ichm. panów litewskich w Grodnie rezydujących [na sejmie 1685]", AGAD, APP, 47, t. 3, s. 450.

${ }^{36}$ A. Rachuba, Sejmiki generalne..., s. 43.

${ }^{37}$ Ibidem, s. 156.

${ }^{38}$ Ibidem, s. 157.
} 
względów, nie poczytali tego za podstawę uznania zjazdu za nielegalny. Właściwe obrady sejmiku trwały zaledwie jeden dzień, podczas którego pozostali w Słonimiu posłowie i senatorowie spisali manifestację przeciw sejmowi warszawskiemu, którą zapewne podali do grodu. Konsekwencją braku akceptacji dla przeniesienia obrad sejmu do Warszawy była decyzja o gremialnym udaniu się na dzień 16 lutego 1685 r. (a więc przewidziany uniwersałem królewskim dzień inauguracji obrad) do Grodna, gdzie zdaniem zgromadzonych powinien odbyć się sejm. Tam też Litwini mieli oczekiwać na przybycie posłów i senatorów z innych części kraju. Wreszcie, aby nie dopuścić do inauguracji obrad warszawskich, zdecydowano o wysłaniu pewnej grupy posłów, która miała z jednej strony poinformować króla i szlachtę zebraną w Warszawie o konieczności odbycia sejmu w Grodnie, z drugiej strony nie pozwolić na rozpoczęcie sejmowania w Koronie ${ }^{39}$. Dopuszczali jednocześnie Litwini pewne ustępstwa, zgadzając się na sejmowanie w Warszawie pod warunkiem, że sejmujący, jeszcze przed obraniem dyrektora izby, uchwalą asekurację potwierdzającą nienaruszalność prawa o sejmie grodzieńskim. Sejmik generalny zakończył się ucztą urządzoną przez Sapiehów, która przeciągnęła się do późnej nocy ${ }^{40}$.

Fakt, że obrady słonimskie skończyły się w ekspresowym tempie, świadczy o tym, że zostały znacznie wcześniej wyreżyserowane. Sapiehowie musieli być pewni nie tylko tego, że sejmik się odbędzie i zakończy szczęśliwie, ale musieli wcześniej założyć i to, że ze Słonimia posłowie i senatorowie litewscy udadzą się nie do Warszawy, ale do Grodna, gdzie zgodnie z prawem miał odbywać się sejm. Dlatego też przystąpili do organizacji specjalnej poczty na trasie między Grodnem a Warszawa za której pośrednictwem wysłani do Warszawy przedstawiciele Wielkiego Księstwa mieli przekazywać informacje do przebywających w Grodnie braci $^{41}$. Wywiad sapieżyński w Warszawie działać musiał znakomicie, skoro obserwatorzy donosili, że Litwini zgoła najmniejszej akcyjej warszawskiej nie tylko publicznej, ale prywatnej srodze rzetelne maja wiadomościt2. O tym, że scenariusz obrad słonimskich napisano jeszcze przed sejmikiem, świadczy pośrednio również fakt, że wielu obywateli Wielkiego Księstwa już wcześniej rezerwowało sobie gospody w Grodnie ${ }^{43}$.

\footnotetext{
39 „Diariusz Stanisława Niezabitowskiego”, BN, BOZ, 911, 6-7 II 1685.

${ }^{40}$ Ibidem, 7 II 1685.

${ }^{41}$ Stanisław Niezabitowski do Zbigniewa Morsztyna, miecznika mozyrskiego, Słuck, 12 II 1685, AGAD, AR V, 10481/V, s. 21-24.

${ }^{42}$ Stanisław Niemira, podczaszy podlaski do Marcina Zamoyskiego, wojewody lubelskiego, Grodno 21 II 1685, Archiwum PAN Warszawa, 398 Teki Wolińskiego, 69, k. 359.

43 „Pewne przestrogi z Księstwa Litewskiego", AGAD, AZ, 3047, s. 159.
} 
Ostatecznie, zgodnie z postanowieniami słonimskimi, zgromadzona tam szlachta podzieliła się. Kilku posłów oddelegowanych zostało do Warszawy, gdzie mieli zająć się blokowaniem obrad. Co interesujące, nie ma pewności, ilu właściwie ich było, a w różnych źródłach podawane są różne dane. Nawet sami Litwini nie wiedzieli, jak liczne jest przedstawicielstwo protestujących, a jeden z czołowych posłów "słonimskich" Bogusław Uniechowski sam miał wątpliwości, iloma "szablami” dysponuje, mówiąc, że przybyło ich do Warszawy tylko sześć, albo ośm ze zjazdu słonimskiego ${ }^{44}$. Prawdopodobnie rację ma A. Rachuba, podając, że posłów litewskich było siedmiu ${ }^{45}$. Do wysłanej ze Słonimia grupy weszli z pewnością: Marcjan Rymkiewicz Polski starosta oszmiański, Aleksander Mosiewicz marszałek i podwojewodzi lidzki, Eliasz Michał Rymwid podkomorzy lidzki, Stefan Eustachy Aleksandrowicz podkomorzy grodzieński, Krzysztof Micuta pisarz ziemski grodzieński, Kazimierz Stanisław Dąbrowski podstoli wileński oraz Bogusław Uniechowski pisarz ziemski nowogródzki. Do Warszawy przybyło wkrótce również kilku senatorów litewskich.

Natomiast do Grodna udali się pozostali senatorowie: Kazimierz Sapieha wojewoda wileński i hetman litewski, Stefan Kurcz wojewoda brzeski, Karol Wilczek kasztelan smoleński, Jan Korczak kasztelan połocki oraz Dominik Radziwiłł podkanclerzy litewski. Towarzyszyło im siedemnastu posłów: Kazimierz Mintowt Czyż podkomorzy wileński (z powiatu wileńskiego), Samuel Hieronim Kociełł marszałek oszmiański (z oszmiańskiego), Kazimierz Frąckiewicz starosta lidzki (z lidzkiego), Konstanty Woyna ciwun tędziagolski (z bracławskiego), Jan Pogirski marszałek rzeczycki (z starodubowskiego), Dominik Słuszka starosta rzeczycki (z starodubowskiego), Janusz Zenowicz podkomorzy połocki wraz z nieznanym kolegą (z województwa połockiego), Krzysztof Kiersnowski podwojewodzi i podkomorzy nowogrodzki (z nowogródzkiego), Krzysztof Połubiński starosta wołkowyski (z wołkowyskiego), Teofil Olenski podkomorzy wołkowyski (z wołkowyskiego), Karol Uniechowski chorąży miński (z mińskiego), Dadźbóg Łukomski wojski witebski (z witebskiego), nieznany z nazwiska poseł z sejmiku orszańskiego oraz Franciszek Chrapowicki i Michał Sokoliński pisarz W.Ks. Lit., posłujący z nieznanych sejmików ${ }^{46}$. Pewne jest, że nie wszyscy zebrani w Słonimiu posłowie zaakceptowali podjęte na zjeździe decyzje. Część z nich wyje-

44 "Synopis relacyjej sejmu warszawskiego Anno 1685 die 16 februarii zaczętego de vero 30 mai skończonego czynionej die 16 juli 1685", BCz, 181, s. 92.

${ }^{45}$ A. Rachuba, Wielkie Księstwo..., s. 164.

${ }^{46}$ "Regestr ichm. panów litewskich w Grodnie rezydujących [na sejmie 1685]”, AGAD, APP, 47, t. 3, s. 450 . 
chała wcześniej, a do Grodna udało się jedynie około połowy obecnych w Słonimiu. Jak zaobserwował naoczny świadek obrad, były to osoby reprezentujące partium Sapiehanarum, którym towarzyszyły gromady szlachty litewskiej, zapewne wchodzącej w skład orszaków senatorskich ${ }^{47}$. Natomiast spora grupa posłów, pewnie widząc jednoznacznie polityczny charakter zjazdu, udała się prosto ze Słonimia do Warszawy ${ }^{48}$. W mieście tym znaleźli się również posłowie litewscy, którzy na sejmik generalny w ogóle nie pojechali. Być może część nie wierzyła, że sejmik dojdzie do skutku, część była zapewne przeciwna inicjatywie jego zwołania. Na marginesie warto dodać, że już w czasie obrad sejmowych w Warszawie grupa parlamentarzystów litewskich kwestionowała prawo posłów „słonimskich" do określania się jako reprezentantów całej Litwy.

Akcja zorganizowana przez Litwinów w 1685 r. wywołała zaniepokojenie na dworze. Pozornie może to dziwić, skoro szlachta litewska miała pełne prawo do organizowania sejmiku generalnego. Na dworze od początku zdawano sobie jednak sprawę z jednoznacznie antykrólewskiego wydźwięku sejmiku. Z tego powodu na radzie senatu we Lwowie, która odbyła się 3 lutego 1685 r. (a więc jeszcze przed zainaugurowaniem przez Litwinów obrad), pojawił się nawet specjalny punkt w tej sprawie, zatytułowany Zjazd słonimski wielkie księstwo Litewskie per modum generałów koronnych formuje. Tego typu zapis stawiał właściwie generał litewski poza strukturą ustrojową Rzeczypospolitej i był możliwy zapewne jedynie dlatego, iż na radzie żaden senator litewski nie był wówczas obecny. Król zastanawiał się z przedstawicielami Korony, co zrobić w razie trudności stwarzanych przez Litwinów na zorganizowanym w Warszawie sejmie. Ostatecznie zdecydowano, że skoro jeszcze nie wiadomo dokładnie, o co chodzi obywatelom Wielkiego Księstwa, decyzja zostanie odłożona do czasu rozpoczęcia sejmu w Warszawie ${ }^{49}$. Zdawano sobie sprawę, że należy postępować niezwykle ostrożnie i delikatnie, o co apelowali obecni w Grodnie obserwatorzy, donosząc o niezwykłej mobilizacji i desperacji zebranych tam Litwinów ${ }^{50}$. Prawdopodobnie jednak otoczenie króla podjęło zakulisowe działania, aby nie dopuścić do masowego zjazdu. Cyprian Paweł Brzostowski w liście do sekretarza króla Stanisława Sarnowskiego dziękował mu nieco enigmatycznie, żeś mię przestrzegat o woli pańskiej, do

\footnotetext{
${ }^{47}$ Stanisław Niemira, podczaszy podlaski do Marcina Zamoyskiego, wojewody lubelskiego, Grodno 21 II 1685, Archiwum PAN Warszawa, 398 Teki Wolińskiego, 69, k. 359.

${ }^{48}$ Stanisław Niezabitowski do Zbigniewa Morsztyna, miecznika mozyrskiego, Słuck, 12 II 1685, AGAD, AR V, 10481/V, s. 21-24.

49 „Senatus consilium we Lwowie”, 3 II 1685, AGAD, AZ, 3047, s. 137-142.

${ }^{50}$ Stanisław Niemira, podczaszy podlaski do Marcina Zamoyskiego, wojewody lubelskiego, Grodno 21 II 1685, Archiwum PAN Warszawa, 398 Teki Wolińskiego, 69, k. 359.
} 
której stosując się i uchodzę z tych zjazdów $w^{51}$. Może z tej wzmianki wynikać, że król przez zaufane osoby rozpoczął akcję, częściowego przynajmniej, storpedowania zjazdu słonimskiego.

Ostatecznie posłowie "słonimscy", którzy pojawili się w Warszawie, skutecznie uniemożliwili obrady sejmu, nie pozwalając na wybór marszałka izby. Dopiero po długich, trwających kilka tygodni targach, zgodzili się na rozpoczęcie obrad sejmowych i wybór dyrektora. Król z senatem i posłami koronnymi poszli na ustępstwa. Sejm grodzieński został „ubezpieczony" nową konstytucją ${ }^{52}$, a z senatu wysłano delegację do Grodna w celu przekonania pozostających tam posłów i senatorów do przybycia na obrady do Warszawy. W ten sposób opozycja litewska zamanifestowała swoją siłę, a więc osiągnęła zamierzony cel. Sejm z 1685 r., który w zamysłach dworu miał być wielkim tryumfem króla i manifestacją wiktorii wiedeńskiej, zaczął się w cieniu zmasowanego ataku opozycji ${ }^{33}$.

Natomiast bez wątpienia należy uznać, że sejmik generalny z $1685 \mathrm{r}$. dla funkcjonowania tej instytucji w Wielkim Księstwie Litewskim był wydarzeniem incydentalnym i niemającym żadnego wpływu na jej faktyczny zanik. Wydarzenie to $\mathrm{w}$ żaden sposób nie przełożyło się również na ożywienie wciąż martwych sejmików generalnych prowincji wielkoi małopolskiej. Zorganizowanie omówionego powyżej zjazdu było możliwe dzięki czasowej współpracy Sapiehów i Radziwiłłów, którzy potrafili zagrać na emocjach szlachty litewskiej, poruszonej łamaniem przez króla świeżo zdobytego prawa o sejmie grodzieńskim. Jednak należy zauważyć, że okoliczności zwołania sejmiku, jego przebieg i konsekwencje miały na sytuację kraju, zarówno wewnętrzna, jak i międzynarodowa, wpływ jednoznacznie negatywny. Dla staropolskiego parlamentu był to kolejny krok $\mathrm{w}$ stronę dalszego pogrążania się $\mathrm{w}$ chaosie - wskutek protestu Litwinów wybór marszałka sejmowego nastąpił dopiero podczas dwudziestej pierwszej sesji sejmowej ${ }^{54}$.

Sama akcja z 1685 r. nie poszła w zapomnienie. W 1692 r., gdy kadencja sejmowa przypadała znów na Litwę, wobec wstępnych sugestii króla, aby kolejny zjazd przenieść do Lwowa, Benedykt Sapieha miał otwarcie manifestować, że sejmik słonimski tym razem na to nie pozwoli55 ${ }^{55} \mathrm{Z}$ kolei

${ }^{51}$ Cyprian Paweł Brzostowski, wojewoda trocki do Stanisława Sarnowskiego, Wilno, 27 I 1685, BCz, 1376, s. 570-571.

52 „Utwierdzenie Seymu Grodzińskiego”, VL, t. V, s. 344.

${ }^{53}$ R. Kołodziej, Echa bitwy wiedeńskiej na sejmie 1685 roku, [w:] Miedzy Barokiem a Oświeceniem. Wielkie bitwy, red. S. Achremczyk, Olsztyn 2010, s. 168-176.

${ }^{54}$ R. Kołodziej, Ostatni wolności..., s. 171.

${ }^{55}$ Stanisław Witwicki biskup poznański do Jana III, b.m., 30 XI 1690, BCz, 183, s. 199 202. 
w 1694 r., w czasie ostrej walki politycznej między Konstantym Brzostowskim biskupem wileńskim a Sapiehami, hasło zwołania sejmiku czy też zjazdu generalnego, pojawiło się ponownie. Pewne informacje wskazują że Litwini rzeczywiście planowali wspólne posiedzenie przed sejmem 1695 r., choć nie wiadomo, jaki charakter miałoby ono przyjąć. Nie wiemy, czy ostatecznie do tego zjazdu doszło ${ }^{56}$. Wiadomo natomiast, że jesienią 1695 r. na Litwie ponownie zaczęto głośno mówić o zwołaniu zjazdu generalnego w Słonimiu. Ponieważ byłby on zdominowany przez stronników sapieżyńskich, biskup Brzostowski w porozumieniu z Karolem Radziwiłłem, podkanclerzym litewskim, planowali zwołać konkurencyjny zjazd $w$ innym miejscu ${ }^{57}$. Obie inicjatywy miały wyraźny kontekst polityczny i nie miały wiele wspólnego z próbą rzeczywistego wskrzeszenia litewskiego sejmiku generalnego. Wydaje się zreszta, że ostatecznie żaden z planowanych sejmików nie doszedł do skutku. Kolejny sejmik generalny litewski (nie w Słonimiu jednak, lecz w Brześciu) zebrał się dopiero w roku $1710^{58}$.

\section{BIBLIOGRAFIA:}

\section{Rękopisy:}

Archiwum Główne Akt Dawnych: Archiwum Publiczne Potockich: 47, t. 3; 48, 162; Archiwum Radziwiłłów, dz. II: 1708, 1739, 1730; dz. V: 1513/I; 10481/V; 11551; Archiwum Zamoyskich: 3047.

Archiwum Państwowe w Poznaniu, Księgi Gr. wschowskie: 149, 150.

Archiwum Polskiej Akademii Nauk, 398, Teki Wolińskiego: 69.

Biblioteka Narodowa, Biblioteka Ordynacji Zamoyskich: 911, 1809, t. 2.

Biblioteka PAU i PAN Kraków: 8338, 8343.

Biblioteka XX Czartoryskich w Krakowie: 181, 183, 431, 1376, 1865.

Geheimes Staatsarchiv Preussische Kulturbesitz Berlin-Dahlem: I HA, Rep. 9, 27.k.3.

Lietuvos Mokslu Akademijos biblioteka, F. 17-57.

Nacyjanalny Gistaryczny Archiu Bielarusi w Mińsku: F. 695, op. 1, nr 102; F. 1737, op. 1, nr 25.

Starodruki i wydawnictwa źródłowe:

Akta sejmikowe województwa krakowskiego, t. IV, opr. A. Przyboś, Wrocław 1963; t. V, opr. Adam Przyboś, Wrocław 1984.

${ }^{56}$ Przed sejmem maja ichm. panowie litewscy w Grodnie się zjechać i znieść się, zob. Andrzej Pezarski do Stanisława Niezabitowskiego, z Wilna, 3 XII 1694, AGAD, AR V, 11551, s. 90. Bez wątpienia była to inicjatywa Sapiehów, którzy starannie przygotowywali się do nadciągającego sejmu, gdzie miało dojść do starcia z obozem dworskim.

${ }^{57}$ Konstanty Brzostowski biskup wileński do Karola Stanisława Radziwiłła podkanclerzego W. Ks. Lit., z Werek, 30 IX 1695, AGAD, AR V, 1513/I, s. 52-54; G. Sliesoriunas, Problem separatyzmu Wielkiego Księstwa Litewskiego w końcu XVII wieku, [w:] Rzeczpospolita wielu narodów i jej tradycje, red. A. K. Link-Lenczowski, M. Markiewicz, Kraków 1999, s. 93.

${ }^{58}$ A. Rachuba, Wielkie Księstwo..., s. 165. 
Akta zjazdów stanów Wielkiego Księstwa Litewskiego, t. II: Okresy panowania królów elekcyjnych XVI-XVII wiek, opr. H. Lulewicz, Warszawa 2009.

G. Lengnich, Geschichte der preußischen Lande polnischen Antheils unter der Regierung der Könige Michaels und Johann des dritten, t. VIII, Danzig 1748.

Pisma polityczne z czasów rokoszu Zebrzydowskiego 1606-1608, wyd. J. Czubek, t. 1-3, Kraków 1916-1918.

Volumina Legum, wyd. J. Ohryzko, t. V, Petersburg 1860.

\section{Literatura:}

Achremczyk S., Życie sejmikowe Prus Królewskich w latach 1647-1772, Olsztyn 1999.

Bobiatyński K., Michat Kazimierz Pac - wojewoda wileński, hetman wielki litewski, Warszawa 2008.

Czarniecka A., Nikt nie stuchat mnie za życia. Jan III Sobieski w walce z opozycyjna propagandq (1684-1696), Warszawa 2009.

Gierowski J. A., Sejmik generalny księstwa mazowieckiego na tle ustroju sejmikowego Mazowsza, Wrocław 1948.

Górna B., Antykrólewska propaganda opozycji (od bitwy wiedeńskiego do sejmu 1685 r.), „Sobótka" 1996, 51, 1-3, s. 147-152.

Górna B., Przygotowanie do zwołania sejmu w 1685 roku, [w:] Studia z dziejów XVII i XVIII w., red. K. Matwijowski, B. Rok, „Prace Historyczne”2003, t. XXXIII, s. 53-55.

Kołodziej R., Echa bitwy wiedeńskiej na sejmie 1685 roku, [w:] Między Barokiem a Oświeceniem. Wielkie bitwy, red. S. Achremczyk, Olsztyn 2010, s. 168-176.

Kołodziej R., Ostatni wolności naszej klejnot. Sejm Rzeczypospolitej za panowania Jana III Sobieskiego, Poznań 2014.

Kriegseisen W., Samorzad szlachecki w Małopolsce w latach 1669-1717, Warszawa 1989.

Malejka A., Spór o pieczęć wielka litewska w latach 1684-1685. Z dziejów polityki nominacyjnej Jana III Sobieskiego, „Studia Historyczne” 2001, 44, 2, s. 301-311.

Naworski Z., Sejmik generalny Prus Królewskich 1569-1772. Organizacja i funkcjonowanie na tle systemu zgromadzeń stanowych prowincji, Torun 1992.

Rachuba A., Sejmiki generalne Wielkiego Księstwa Litewskiego w Wołkowysku i Słonimiu, [w:] Między Zachodem a Wschodem. Studia z dziejów Rzeczypospolitej w epoce nowożytnej, red. J. Staszewski, K. Mikulski, J. Dumanowski, Toruń 2002, s. 42-53.

Rachuba A., Wielkie Księstwo Litewskie w systemie parlamentarnym Rzeczypospolitej w latach 1569-1763, Warszawa 2002.

Semkowicz W., Udział wojsk litewskich Sobieskiego w kampanii roku 1683, „Ateneum Wileńskie" 1934, 9, s. 7-20.

Skrzypietz A., Królewscy synowie - Jakub, Aleksander i Konstanty Sobiescy, Katowice 2011.

Sliesoriunas G., Problem separatyzmu Wielkiego Księstwa Litewskiego w końcu XVII wieku, [w:] Rzeczpospolita wielu narodów i jej tradycje, red. A. K. Link-Lenczowski, M. Markiewicz, Kraków 1999, s. 85-94.

Wagner M., Stanisław Jabłonowski (1634-1702). Polityk i dowódca, t. 1, Siedlce 1997.

Wójcik Z., Jan Sobieski, Warszawa 1994.

\section{ABSTRACT:}

The general dietine (sejmik) of the Grand Duchy of Lithuania became a non-functioning body in the first half of the 17th century. That is why organizing an assembly in Słonim in 1685 by Lithuanians made a great impression all over the country. Its success 
was possible thanks to the combined influences of the Sapieha and the Radziwiłf families, who united against the king for a short period of time. This initiative was triggered by the decision of the king and the Senate council on moving the 1685 sejm from Grodno to Warsaw, which caused protests of Lithuanians. As a result, it was easier to stir turmoil against the policy of the court among them. The citizens of the Grand Duchy of Lithuania who gathered in Słonim sent a few representatives to the sejm in Warsaw to block the election of the marshal. At the same time the majority of the participants of the Stonim assembly went to Grodno as the rightful place of the sejm. It was only after a few weeks of negotiations that the king managed to convince Lithuanians to agree to come to Warsaw. However, they managed to accomplish their aim of demonstrating their dissatisfaction and hampered the celebration of the Vienna victory, which was supposed to strengthen the king's authority. During the assembly a new constitution was passed, securing the sejm in Grodno. However, the events of 1685 did not have much influence on the very institution of the Lithuanian general sejmik, which continued to be a non-functioning body in the subsequent years.

Key words: diet (sejm), dietine (sejmik), general dietine, Grand Duchy of Lithuania, parliamentary system, Jan III Sobieski, Sapiehowie, Radziwiłłowie, Grodno, Słonim

\section{NOTA O AUTORZE}

Dr hab. Robert Kołodziej - pracownik naukowy Instytutu Historycznego Uniwersytetu Wrocławskiego. Jego zainteresowania badawcze koncentrują się na dziejach staropolskiego parlamentaryzmu: sejmów, sejmików i rad senatu. Zajmuje się również staropolską kulturą polityczną i dyplomacją przede wszystkim stosunkami Rzeczypospolitej z Imperium Osmańskim. Jest autorem trzech książek i kilkudziesięciu artykułów naukowych. Kontakt z Autorem: kolodziej69@op.pl. 